\title{
Determination of trace metal concentrations in a flooded tropical lake during a complete hydrological cycle
}

\author{
W. J. Barreto ${ }^{*}$, M. Reche Ribeiro ${ }^{1}$, I. S. Scarminio ${ }^{2}$, M. C. Solci², J. Nozaki ${ }^{3}$, E. de Oliveira ${ }^{4}$, S. R. Giancoli \\ Barreto $^{5}$ \\ ${ }^{1}$ Laboratory of Environmental Physical Chemistry, Department of Chemistry, CP 6001, Londrina State University, 86051-990, Londrina, \\ Paraná, Brazil. \\ 2 Department of Chemistry, Londrina State University, 86051-990, Londrina, Paraná, Brazil. \\ 3 Department of Chemistry, Maringa State University, 87020-900, Maringa, Paraná, Brazil. \\ ${ }^{4}$ Institute of Chemistry, University of São Paulo, São Paulo, São Paulo, Brazil. \\ 5 Graduate Program in Ecology of Aquatic and Continental Environments, Maringa State University, Av. Colombo, 5790. Maringa, PR, Brazil.
}

\begin{abstract}
The concentrations of the $\mathrm{Al}, \mathrm{Co}, \mathrm{Cr}, \mathrm{Cu}, \mathrm{Pb}, \mathrm{Sn}, \mathrm{Ni}$, and $\mathrm{Zn}$ trace metals were monitored in Lake Ipê (Brazil) during two hydrological sub-periods : June - December 1999 (low water period, LW), and January - April 2000 (high water period, HW). A detailed study of the physical and chemical state of the metals was performed through the MINTEQA2 computer program using 15 abiotic parameters. An increase in concentration of many trace metals in July 1999 was due to the sudden entry of allochthonous matter. The seasonal study showed that the metal concentrations in the lake were governed by the hydrological regime of the Paran. River (HW), and by the occurrence of occasional flood pulses and rainfall (LW).
\end{abstract}

Keywords : lakes, freshwater, trace metals, ICP-OES, MINTEQA2.

\section{Introduction}

The chemical composition of natural waters is determined by several factors. Many terrestrial and aquatic organisms disturb the substratum (soil, sediment) in which they grow and live, thus extracting chemical substances from the environment, and excreting others that may affect the chemistry of natural waters. Geochemical processes, such as the erosion of the earth's crust by rain, and the incorporation of inorganic ions dissolved in the sediment, after the formation of insoluble components or adsorption on particles in suspension, are among the factors that dominate the concentration control of inorganic elements in water (Buffle 1990).

The river-floodplain systems of tropical regions are

\footnotetext{
* Corresponding author :

E-mail: barreto@uel.br
}

submitted to very particular climatic and environmental conditions, causing remarkable temporal variations in abiotic parameters. Alterations in these parameters are mainly related to changes in hydrometrical levels, called « flood pulse » by Junk et al. (1989), and having two phases, flood and drought (Neiff 1990). Lake Ipê, Brazil, which belongs to the Paraná River plain is a typical tropical lake in a flooded area suffering from such type of variation. A previous study described the seasonal variations of abiotic parameters and metals (Fe, $\mathrm{Mn}$ and $\mathrm{Cd}$ ) in this lake (Barreto et al 2005). Other limnological parameters, such as trace metal concentrations, are still unknown in this area, and this work is the first to study trace metal occurrence in these waters during a complete hydrological cycle. The water regime in this area is regulated by Itaipu (southwest-downstream) and Ilha Solteira (northeast-upstream) dams. The main tributary of the Parana River is the Tietê River coming from S. Paulo city (about 300 $\mathrm{km}$ upstream). S. Paulo is the largest city of South 
America (over 10,000,000 inhabitants), and hosts the largest Latin America industrial park, with practically no treatment of domestic and industrial wastewaters. Therefore, the Parana River suffers from consequences of several pollutants released by industrial and agricultural activities. Several and water quality studies have been performed in the Tietê River basin, always upstream from the Ilha Solteira dam. However there is a lack of knowledge downstream from the dam. It is important to study if and how these massive waste matters could affect the water of Lake Ipê.

The aim of this work was therefore to verify whether the seasonal variations of trace metals from June/99 until June/00 in Lake Ipê were associated with the water level of the Paraná River and/or the local rainfall, and to estimate the chemical speciation of metals using the MINTEQA2 computer program.

\section{Methods}

\section{Study area}

The upper Paraná basin occupies a vast area, over $802,150 \mathrm{~km}^{2}$ in the Brazilian territory. The upper course of the Paraná River is dammed 120 miles downstream by the Itaipu Hydroelectric Plant (HEP), and 80 miles upstream by the Porto Primavera and Jupiá HEPs. The Paraná River channel, secondary channels, and their tributaries form the region's drainage network.

Lake Ipê (Brazil) which belongs to the Paraná River plain, is located on the right bank of the Curutuba Channel. The lake is surrounded by herbal and arboreal vegetation and, on the banks, by aquatic macrophytes, especially Eichhornia crassipes and Eichhornia azurea. Lake Ipê is in constant communication wi-

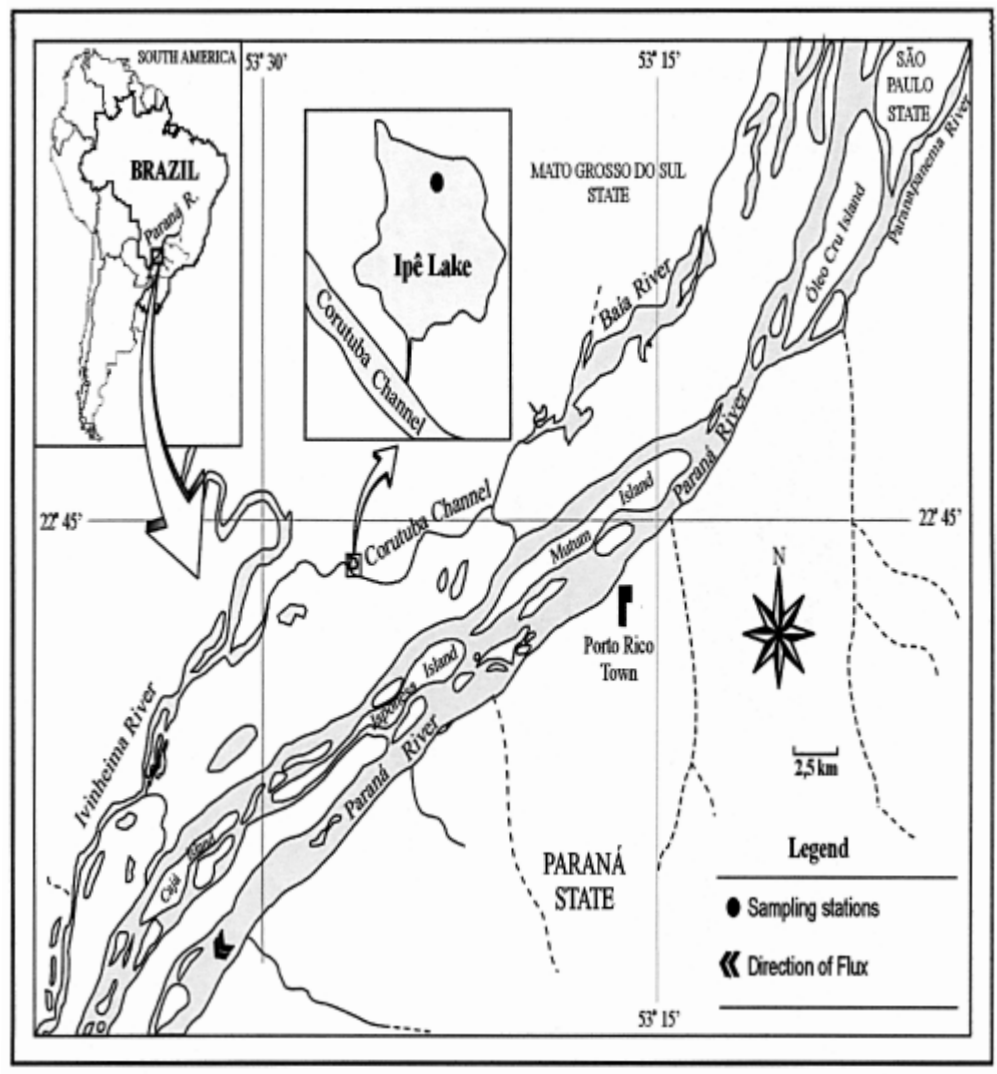

Fig. 1. Location of Paraná River and Lake Ipê. The flow directions of the Parana River is from the Northeast to the Southwest, and that of the Ivinheima River is from the Northwest to the Southwest, as shown. Lake Ipê is located at the right margin of the Curutuba Channel, between the Ivinheima and Baia Rivers, Mato Grosso do Sul, Brazil. 
th the Curutuba Channel by means of a small, narrow channel, and its maximum depth varies from 1.5 to 3.0 $\mathrm{m}$ from low waters (LW) to high waters (HW). The lake area was determined as $110,764 \mathrm{~m}^{2}$ by measurements carried out by GPS. The lake was sampled at the deepest place which is at an elevation of $270 \mathrm{~m}$ above sea level, located at S $22^{\circ} 45^{\prime} 57^{\prime \prime}$ and W 53 ${ }^{\circ} 26^{\prime} 38^{\prime \prime}$ (Fig. 1).

\section{Sampling and analytical methods}

A vertical profile of Lake Ipê was obtained by monthly water collections between June 1999 and June 2000 (i.e., 13 samples) at the lake's deepest part (Fig. 1). The samples were collected at $50 \mathrm{~cm}$-intervals, from the surface to the bottom. Since the depth of the lake did not remain constant during the study period, the bottom samples were collected at $1.5 \mathrm{~m}$ in December 1999 and May 2000, at $2.5 \mathrm{~m}$ in July 1999 and March 2000, and at $2.0 \mathrm{~m}$ during the remaining months (Fig 2B). In previous analyses, statistical variations were not observed when the studies were carried out using lake depths as parameters. Thus, the values of physical-chemical parameters and metal concentrations correspond to the arithmetic means of the values obtained for each depth analyzed. The average standard deviation for each set of data may be evaluated by the dimensions of the error bars in the figures. The samples were collected with Van Dorn's bottle and stored in plastic mineral water bottles, previously cleansed with nitric acid $10 \%$, rinsed out several times with lake water and kept in the dark in an isothermal box filled with ice until analysis.

The $\mathrm{pH}$ measurements (Hanna Instruments model Hi 9321), water temperature, and DO (YSI-52-YSI Corporation-USA field measurers), $\mathrm{pE}$ (Digimed model $\mathrm{DM} / 10$ - pH/ORP), and electrolytic conductivity (Hanna Instruments model HI $8819 \mathrm{~N}$ ) were carried out at the place of collection. The water samples were filtered through $0.45 \mu \mathrm{m}$ cellulose ester Millipore filters and placed in a « Millipore Sterifil Holder » type of filtration equipment with a stainless steel suspender. Before the samples were collected, the filters were washed with $500 \mathrm{ml}$ ultra-pure water (Milli-Q). The sets of containers used in filtration had been previously washed in $\mathrm{HNO}_{3} 20 \%$ (Merck). The polyethylene packages destined for the storage of samples and laboratory utensils were washed, kept in $\mathrm{HNO}_{3} 20 \%$ for $48 \mathrm{~h}$, rinsed several times in deionized water, placed in a stove at $60^{\circ} \mathrm{C}$ for drying, closed and shut. A volume of $500 \mathrm{ml}$ samples of non-filtered and filtered water was acidified with $5 \mathrm{ml} \mathrm{HNO}_{3} 1 \%(\mathrm{v} / \mathrm{v})$, stored and kept at $4^{\circ} \mathrm{C}$ until the pre-concentration procedure. In triplica-

Table 1. Physical and chemical parameters in Lake Ipê (1999-2000).

\begin{tabular}{|c|c|c|c|c|c|c|c|c|c|c|c|c|c|c|}
\hline $\begin{array}{l}\text { Month/ } \\
\text { Year }\end{array}$ & $\mathrm{pH}$ & $\begin{array}{l}\mathrm{Eh} / \\
\mathrm{mV}\end{array}$ & $\begin{array}{l}\mathrm{T} / \\
{ }^{\circ} \mathrm{C}\end{array}$ & $\begin{array}{l}\text { Conductivity/ } \\
\qquad \mu \mathrm{S} / \mathrm{cm}\end{array}$ & $\begin{array}{l}\text { Alkalinity } \\
\mathrm{C} / \mathrm{mg} \mathrm{l}^{-1}\end{array}$ & $\begin{array}{c}\text { Dissolved } \\
\mathrm{O}_{2} \\
\mathrm{C} / \mathrm{mg}^{-1}\end{array}$ & $\begin{array}{c}\text { Chlorophyll } \\
\text { a } \\
\mathrm{C} / \mu \mathrm{g} \mathrm{l}^{-1}\end{array}$ & $\begin{array}{c}\mathrm{SiO}_{4} \\
\mathrm{C} / \mathrm{mg} \mathrm{l}^{-1}\end{array}$ & $\begin{array}{c}\mathrm{DOC} \\
\mathrm{C} / \mathrm{mg} \mathrm{l}^{-1}\end{array}$ & $\begin{array}{l}\text { Ortho P } \\
\mathrm{C} / \mu \mathrm{g} \mathrm{l^{-1 }}\end{array}$ & 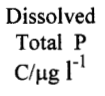 & $\begin{array}{c}\mathrm{NO}_{3}{ }^{-} \\
\mathrm{C} / \mathrm{mg} \mathrm{l}^{-1}\end{array}$ & $\begin{array}{c}\mathrm{S}^{-\mathrm{SO}_{4}} \\
\mathrm{C} / \mathrm{mg} \mathrm{l}^{-1}\end{array}$ & $\begin{array}{c}\text { Dissolved } \\
\text { Total S } \\
{\mathrm{C} / \mathrm{mg} \mathrm{l}^{-1}}^{-1}\end{array}$ \\
\hline $\begin{array}{c}\text { Jun/ } \\
1999\end{array}$ & $\begin{array}{c}6.42 \\
(0.04)\end{array}$ & $\begin{array}{l}304 \\
(0)\end{array}$ & $\begin{array}{l}20.2 \\
(0.3)\end{array}$ & $\begin{array}{l}23.4 \\
(1.5)\end{array}$ & $\begin{array}{c}8.3 \\
(0.9)\end{array}$ & 6.48 & $\begin{array}{l}13.3 \\
(1.3)\end{array}$ & 11.3 & 6.23 & 1.0 & 3.0 & $\begin{array}{c}0.39 \\
0.016\end{array}$ & 0.16 & $\begin{array}{c}0.24 \\
(0.04)\end{array}$ \\
\hline $\mathrm{Jul}$ & $\begin{array}{c}5.73 \\
(0.03)\end{array}$ & $\begin{array}{l}249 \\
(3)\end{array}$ & $\begin{array}{c}19.1 \\
0.6\end{array}$ & $\begin{array}{l}36.7 \\
(5.7)\end{array}$ & $\begin{array}{c}8.8 \\
(0.2)\end{array}$ & $\begin{array}{c}2.58 \\
(0.16)\end{array}$ & $\begin{array}{c}4.6 \\
(0.3)\end{array}$ & $\begin{array}{c}4.7 \\
(1.9)\end{array}$ & $\begin{array}{l}14.81 \\
(0.38)\end{array}$ & $\begin{array}{c}9.0 \\
(3.0)\end{array}$ & $\begin{array}{l}17.0 \\
(1.2)\end{array}$ & $\begin{array}{c}0.72 \\
(0.13)\end{array}$ & $\begin{array}{l}1.16 \\
(0.04)\end{array}$ & $\begin{array}{c}1.48 \\
(0.04)\end{array}$ \\
\hline Aug & $\begin{array}{c}6.05 \\
(0.04)\end{array}$ & $\begin{array}{l}265 \\
(9)\end{array}$ & $\begin{array}{l}20.2 \\
(0.8)\end{array}$ & $\begin{array}{l}24.2 \\
(5.5)\end{array}$ & $\begin{array}{c}7.3 \\
(0.1)\end{array}$ & $\begin{array}{c}6.41 \\
(0.49)\end{array}$ & $\begin{array}{l}13.5 \\
(1.4)\end{array}$ & $\begin{array}{c}8.8 \\
(1.0)\end{array}$ & $\begin{array}{l}11.41 \\
(0.51)\end{array}$ & $\begin{array}{c}3.0 \\
(1.0)\end{array}$ & $\begin{array}{c}9.0 \\
(0.8)\end{array}$ & $\begin{array}{c}0.41 \\
(0.06)\end{array}$ & $\begin{array}{c}0.35 \\
(0.07)\end{array}$ & $\begin{array}{c}0.61 \\
(0.02)\end{array}$ \\
\hline Sep & $\begin{array}{l}6.96 \\
(0.10)\end{array}$ & $\begin{array}{l}199 \\
(30)\end{array}$ & $\begin{array}{l}25.5 \\
(0.3)\end{array}$ & $\begin{array}{l}31.0 \\
(2.5)\end{array}$ & $\begin{array}{l}12.4 \\
(0.4)\end{array}$ & $\begin{array}{c}9.22 \\
(0.48)\end{array}$ & $\begin{array}{l}24.6 \\
(2.2)\end{array}$ & $\begin{array}{l}15.5 \\
(0.8)\end{array}$ & $\begin{array}{c}4.03 \\
(0.13)\end{array}$ & $\begin{array}{c}4.0 \\
(0.3)\end{array}$ & $\begin{array}{c}4.0 \\
(0.4)\end{array}$ & $\begin{array}{c}0.34 \\
(0.03)\end{array}$ & $\begin{array}{c}0.33 \\
(0.01)\end{array}$ & $\begin{array}{c}0.50 \\
(0.01)\end{array}$ \\
\hline Oct & $\begin{array}{c}6.93 \\
(0.04)\end{array}$ & $\begin{array}{l}194 \\
(5)\end{array}$ & $\begin{array}{l}22.8 \\
(0.3)\end{array}$ & $\begin{array}{l}30.2 \\
(7.7)\end{array}$ & $\begin{array}{l}10.8 \\
(0.7)\end{array}$ & $\begin{array}{c}10.9 \\
(1.39)\end{array}$ & $\begin{array}{l}26.1 \\
(0.8)\end{array}$ & $\begin{array}{c}9.7 \\
(0.3)\end{array}$ & $\begin{array}{c}4.43 \\
(0.15)\end{array}$ & $\begin{array}{c}3.0 \\
(0.6)\end{array}$ & $\begin{array}{c}3.0 \\
(0.2)\end{array}$ & $\begin{array}{c}0.43 \\
(0.10)\end{array}$ & $\begin{array}{c}0.30 \\
(0.02)\end{array}$ & $\begin{array}{c}0.25 \\
(0.01)\end{array}$ \\
\hline Nov & $\begin{array}{c}6.91 \\
(0.04)\end{array}$ & $\begin{array}{l}211 \\
(23)\end{array}$ & $\begin{array}{l}25.5 \\
(0.2)\end{array}$ & $\begin{array}{l}36.2 \\
(4.2)\end{array}$ & $\begin{array}{l}11.2 \\
(0.9)\end{array}$ & $\begin{array}{c}6.90 \\
(0.37)\end{array}$ & $\begin{array}{l}17.2 \\
(1.1)\end{array}$ & $\begin{array}{l}12.5 \\
(0.4)\end{array}$ & $\begin{array}{c}4.06 \\
(0.72)\end{array}$ & $\begin{array}{c}1.0 \\
(0.6)\end{array}$ & $\begin{array}{c}3.0 \\
(0.3)\end{array}$ & $\begin{array}{c}0.14 \\
(0.06)\end{array}$ & $\begin{array}{c}0.26 \\
(0.02)\end{array}$ & $\begin{array}{c}0.38 \\
(0.01)\end{array}$ \\
\hline Dec & $\begin{array}{c}6.59 \\
(0.06)\end{array}$ & $\begin{array}{l}235 \\
(32)\end{array}$ & $\begin{array}{l}26.8 \\
(0.3)\end{array}$ & $\begin{array}{l}35.3 \\
(2.1)\end{array}$ & $\begin{array}{l}11.6 \\
(0.1)\end{array}$ & $\begin{array}{c}4.05 \\
(0.06)\end{array}$ & $\begin{array}{l}24.1 \\
(0.8)\end{array}$ & $\begin{array}{c}6.7 \\
(1,6)\end{array}$ & $\begin{array}{c}5.72 \\
(0.24)\end{array}$ & $\begin{array}{c}4.0 \\
(1.0)\end{array}$ & $\begin{array}{l}11.0 \\
(0.9)\end{array}$ & $\begin{array}{c}0.38 \\
(0.26)\end{array}$ & $\begin{array}{c}0.24 \\
(0.01)\end{array}$ & $\begin{array}{c}0.31 \\
(0.04)\end{array}$ \\
\hline $\begin{array}{c}\text { Jan/ } \\
2000\end{array}$ & $\begin{array}{l}6.67 \\
(0.02)\end{array}$ & $\begin{array}{l}205 \\
(19)\end{array}$ & $\begin{array}{l}29.7 \\
(0.6)\end{array}$ & $\begin{array}{l}38.6 \\
(5.0)\end{array}$ & $\begin{array}{l}14.2 \\
(0.2)\end{array}$ & $\begin{array}{c}6.16 \\
(0.81)\end{array}$ & $\begin{array}{l}20.0 \\
(0,8)\end{array}$ & $\begin{array}{l}18.9 \\
(1.7)\end{array}$ & $\begin{array}{c}6.27 \\
(0.23)\end{array}$ & $\begin{array}{c}4.0 \\
(1.0)\end{array}$ & $\begin{array}{c}7.0 \\
(0.9)\end{array}$ & $\begin{array}{c}0.96 \\
(0.42)\end{array}$ & $\begin{array}{c}0.13 \\
(0.01)\end{array}$ & $\begin{array}{c}0.31 \\
(0.02)\end{array}$ \\
\hline $\mathrm{Feb}$ & $\begin{array}{c}6.90 \\
(0.04)\end{array}$ & $\begin{array}{l}249 \\
(17)\end{array}$ & $\begin{array}{l}26.9 \\
(0.1)\end{array}$ & $\begin{array}{l}32.8 \\
(8.2)\end{array}$ & $\begin{array}{l}11.6 \\
(0.1)\end{array}$ & $\begin{array}{c}1.78 \\
(0.50)\end{array}$ & $\begin{array}{l}13.9 \\
(2.0)\end{array}$ & $\begin{array}{l}15.1 \\
(3.1)\end{array}$ & $\begin{array}{c}5.14 \\
(0.98)\end{array}$ & $\begin{array}{c}5.0 \\
(1.0)\end{array}$ & $\begin{array}{c}8.0 \\
(1.2)\end{array}$ & $\begin{array}{c}1.19 \\
(0.34)\end{array}$ & $\begin{array}{c}0.20 \\
(0.01)\end{array}$ & $\begin{array}{c}0.29 \\
(0.01)\end{array}$ \\
\hline Mar & $\begin{array}{c}6.57 \\
(0.05)\end{array}$ & $\begin{array}{l}226 \\
(20)\end{array}$ & $\begin{array}{l}26.8 \\
(0.1)\end{array}$ & $\begin{array}{l}39.0 \\
(6.5)\end{array}$ & $\begin{array}{r}14.3 \\
(0.2)\end{array}$ & $\begin{array}{c}2.78 \\
(2.20)\end{array}$ & $\begin{array}{l}11.7 \\
(2.7)\end{array}$ & $\begin{array}{l}13.9 \\
(1.2)\end{array}$ & $\begin{array}{l}19.01 \\
(0.76)\end{array}$ & $\begin{array}{l}14.0 \\
(1.0)\end{array}$ & $\begin{array}{l}37.0 \\
(1.0)\end{array}$ & $\begin{array}{c}0.76 \\
(0.38)\end{array}$ & $\begin{array}{c}0.21 \\
(0.03)\end{array}$ & $\begin{array}{c}0.47 \\
(0.01)\end{array}$ \\
\hline Apr & $\begin{array}{c}6.54 \\
(0.02)\end{array}$ & $\begin{array}{l}232 \\
(4)\end{array}$ & $\begin{array}{l}27.2 \\
(0.1)\end{array}$ & $\begin{array}{l}54.2 \\
(1.5)\end{array}$ & $\begin{array}{l}19.0 \\
(0.1)\end{array}$ & $\begin{array}{c}2.34 \\
(0.18)\end{array}$ & $\begin{array}{l}33.4 \\
(2.1)\end{array}$ & $\begin{array}{l}20.5 \\
(2.6)\end{array}$ & $\begin{array}{l}38.42 \\
(1.02)\end{array}$ & $\begin{array}{l}27.0 \\
(2.0)\end{array}$ & $\begin{array}{l}51.0 \\
(0.9)\end{array}$ & $\begin{array}{c}2.15 \\
(1.10)\end{array}$ & $\begin{array}{c}0.09 \\
(0.01)\end{array}$ & $\begin{array}{c}0.45 \\
(0.01)\end{array}$ \\
\hline May & $\begin{array}{l}6.62 \\
(0.04)\end{array}$ & $\begin{array}{l}226 \\
(7)\end{array}$ & $\begin{array}{c}19.4 \\
(0.3)\end{array}$ & $\begin{array}{l}32.0 \\
(6.7)\end{array}$ & $\begin{array}{l}11.9 \\
(0.2)\end{array}$ & $\begin{array}{c}3.28 \\
(0.15)\end{array}$ & $\begin{array}{l}11.4 \\
(0.9)\end{array}$ & $\begin{array}{l}11.4 \\
(2.8)\end{array}$ & $\begin{array}{c}5.81 \\
(0.48)\end{array}$ & $\begin{array}{c}3.0 \\
(0.3)\end{array}$ & $\begin{array}{c}5.0 \\
(1.4)\end{array}$ & $\begin{array}{c}0.43 \\
(0.05)\end{array}$ & $\begin{array}{c}0.25 \\
(0.02)\end{array}$ & $\begin{array}{c}0.39 \\
(0.01)\end{array}$ \\
\hline Jun & $\begin{array}{c}6.71 \\
(0.05) \\
\end{array}$ & $\begin{array}{r}194 \\
(19) \\
\end{array}$ & $\begin{array}{r}21.0 \\
(0.1) \\
\end{array}$ & $\begin{array}{r}38.0 \\
(0.7) \\
\end{array}$ & $\begin{array}{r}12.6 \\
(0.1) \\
\end{array}$ & $\begin{array}{c}5.92 \\
(0.34) \\
\end{array}$ & $\begin{array}{l}17.1 \\
(1.8) \\
\end{array}$ & $\begin{array}{l}14.9 \\
(0.9) \\
\end{array}$ & $\begin{array}{c}6.38 \\
(0.25) \\
\end{array}$ & $\begin{array}{c}5.0 \\
(1.5) \\
\end{array}$ & $\begin{array}{c}6.0 \\
(0.6)\end{array}$ & $\begin{array}{c}0.49 \\
(0.04)\end{array}$ & $\begin{array}{c}0.17 \\
(0.02)\end{array}$ & $\begin{array}{c}0.31 \\
(0.01)\end{array}$ \\
\hline
\end{tabular}

Values in parenthesis are standard deviation of the values obtained for each depth analysed. $\mathrm{C}$ is the symbol of the concentration. 
te, the sub-samples of non-filtered and filtered water of each depth, accompanied by two blanks $(500 \mathrm{ml}$ of ultra-pure non-filtered water and water filtered in a filter of $0.45 \mu \mathrm{m}$ and $5 \mathrm{ml}$ of $\left.\mathrm{HNO}_{3} 1 \%(\mathrm{v} / \mathrm{v})\right)$ were preconcentrated to approximately $20 \mathrm{ml}$ at $60^{\circ} \mathrm{C}$. The samples were transferred to $25 \mathrm{ml}$ volumetric flasks, completed with ultra-pure water, stored and kept at $4^{\circ} \mathrm{C}$ until analysis by atomic emission spectrometry with induced argon plasma (ICP-OES) (Spectroflame Spectro Analytical Instrument - ICP). The metals present in the non-filtered and acidified water samples were represented by total metal and in filtered and acidified water samples by dissolved metal. The solid residues retained in the filter, defined as particulate metals, were the differences between non-filtered and filtered water samples.

Multivariate analysis was applied to the experimental data using the ARTHUR computer program (Scarminio \& Bruns 1989). The values of the physical-chemical parameters (Table 1) and metal concentrations correspond to the arithmetic means of the values obtained for each depth analyzed. The columns were autoscaled to obtain values with a zero mean and a variance equal to 1 . Principal components analysis (PCA) and Pearson's correlation coefficient calculations at the $95 \%$ confidence interval were applied to the resulting matrix (Scarminio \& Bruns 1989). Theoretical calculations of geochemical equilibrium were carried out by using the MINTEQA2 computer program (Allison et al 1999), adapted to the Windows environment called VisualMINTEQ, version 1.03 (Gustafsson 2001). Calculations were performed using all the physical chemical parameters observed in Lake Ipê (Table 1) dissolved organic carbon (DOC), dissolved oxygen (DO), $\mathrm{pH}$, reactive silica, phosphorus, sulphate, chlorophyll-a, nitrate, water temperature, conductivity, redox potential (Eh), alkalinity and all the metals analyzed (Fe, Mn, Al, Cd, Co, Cr, Cu, Pb, Sn, Ni, and $\mathrm{Zn}$ ).

\section{Results and discussion}

The period ranging from June 1999 to June 2000 was divided into two sub-periods, according to the Lake Ipê and Paraná River water levels (Figs 2 B and 2C, respectively). The period extending from June to December 1999 was characterized as low waters (LW) and the second sub-period, called high waters (HW), extended from January 2000 to mid-April 2000. The months of May 2000 and June 2000 corresponded to the next LW sub-period (Barreto et al 2004). The LW period may be considered to be of greater hydrological stability because of the absence or scarcity of flood

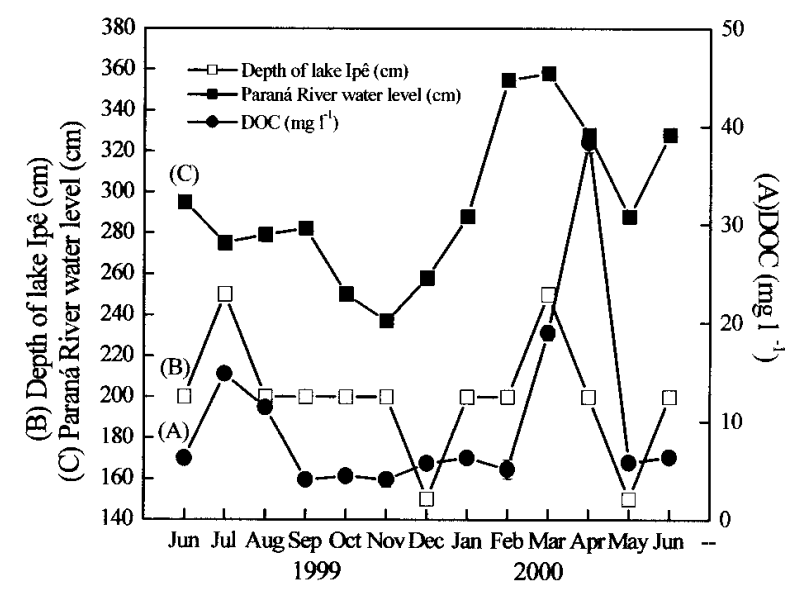

Fig. 2. (A) Concentration $\left(\mathrm{mg} \mathrm{l}^{-1}\right)$ of dissolved organic carbon (DOC) ; (B) depth of Lake Ipê (cm) ; (C) hydrometric levels of Paraná River (cm), from June 1999 to June 2000.

pulses (Train \& Rodrigues 1997). Such hydrological stability of Lake IpÍ was disturbed in July 1999, where an increase in the rainfall and water level of Lake Ipê occurred, whereas there were practically no alterations in the water levels of the Paraná River (Figs 2B, 2C).

Figure 2A shows the annual distribution of DOC concentration. The presence of two peaks was verified in July 1999 (LW) $\left(14.81 \pm 0.38 \mathrm{mg} \mathrm{l}^{-1}\right)$, and in April 2000 (38.42 $\pm 1.03 \mathrm{mg} \mathrm{l}^{-1}$, beginning in March 2000 with $\left.19.01 \pm 0.77 \mathrm{mg} \mathrm{l}^{-1}\right)(\mathrm{HW})$. The first DOC peak coincided with the first value of the lake maximum depth $(2.5 \mathrm{~m})$, and the second DOC peak (April 2000) occurred 30 days after the second greatest depth of the lake (2.5 $\mathrm{m}$ in March 2000). Due to the high values of the relation A (254 $\mathrm{nm}) /$ DOC $\left(\mathrm{g} \mathrm{l}^{-1}\right)$ in July 1999 $\left(65.08 \pm 8.181 \mathrm{~g}^{-1}\right)$, April $2000\left(42.67 \pm 2.96 \mathrm{lg}^{-1}\right)$, and March $2000\left(36.66 \pm 6.661 \mathrm{~g}^{-1}\right)$, Lake Ipê could be characterized, at least during those months, as predominantly fulvic (Barreto et al. 2003). Vegetation, climate, and hydrologic conditions are important factors that contribute to organic carbon lixiviation from the terrestrial ecosystem (Kortelainen 1999). Probably, the increase of DOC in July 1999 was due to the lixiviation of the bank regions and flooding of the lake banks. The aquatic macrophyte communities that emerged there produce a large quantity of biomass, draining towards the inner part of the lake, and suffer decomposition during its permanence. Therefore, the vegetal organic matter decomposition occurred in a semi-closed environment, with the quantity of fulvic matter present in waters almost on a constant basis, monthly, except in July 1999. In HW the organic matter originated 
mostly from the Paraná River indicating that the increase in the Paraná River level brings more homogenous alterations in the environmental conditions of Lake Ipê, due to the slower and continuous level rise during several months.

\section{Trace metals concentration variation}

Aluminum - Figure 3A shows the distribution of the total and dissolved $\mathrm{Al}$ concentrations. In LW (except for July 1999), the concentrations of total and dissolved Al were $118 \pm 25 \mu \mathrm{g} \mathrm{l}^{-1}$ and $42 \pm 27 \mu \mathrm{g} \mathrm{l}^{-1}$. In July 1999 , the concentrations of $\mathrm{Al}$ increased and the values determined were $213 \pm 7 \mu \mathrm{g} \mathrm{l}^{-1}$ total $\mathrm{Al}$ and $152 \pm$ $3 \mu \mathrm{g} \mathrm{l}^{-1}$ of dissolved Al. Concentrations of total and dissolved $\mathrm{Al}$ remained constant between $153 \pm 26 \mu \mathrm{g}$ $\mathrm{l}^{-1}$ and $93 \pm 10 \mu \mathrm{g} \mathrm{l}^{-1}$ during the HW period.

The percentage of particulate $\mathrm{Al}$ in $\mathrm{LW}$, except in $\mathrm{Ju}-$ ly 1999 , was higher than $65 \%$, contrary to the HW value, for which the concentration of dissolved Al had a greater predominance. Such values for Al concentrations are coherent with the lake $\mathrm{pH}=6.58$. According to Borg (1995), Al presents a minimum solubility of around $\mathrm{pH} 6.00$, but in acid or alkaline conditions, or in the presence of complexes, it may be found in high concentrations in waters. Studies of the correlations among all variables also confirmed the linking of dissolved Al with $\mathrm{pH}$, because the correlation between these two variables was -0.700 .

Figures 3B, 3C, 4A-C, and 5A-C show the distribution of $\mathrm{Cd}, \mathrm{Co}, \mathrm{Cr}, \mathrm{Cu}, \mathrm{Ni}, \mathrm{Zn}, \mathrm{Pb}$ and $\mathrm{Sn}$ in samples of non-filtered acidified water (total metal) and filtered acidified water (dissolved metal).

Cadmium - Cadmium was the most relevant trace metal found in the Lake Ipê due to its toxicity and dissolved Cd was important in the discrimination of the water samples collected in March and April 2000 together with Fe and Mn metals (Barreto et al 2005). In the $\mathrm{HW}$ period, the highest concentrations of dissolved $\mathrm{Cd}$ started in March $\left(0.50 \pm 0.05 \mu \mathrm{g} \mathrm{l}^{-1}\right)$ and reached their maximum in April 2000 (0.95 $\left.\pm 0.05 \mu \mathrm{g} \mathrm{l}^{-1}\right)$ (Fig. 3B).

Cobalt - Two peaks of maximum concentration were observed in the distribution of total Co, Fig. 3C, in July $1999\left(0.64 \pm 0.03 \mu \mathrm{g} \mathrm{l}^{-1}\right)(\mathrm{LW})$ and April 2000

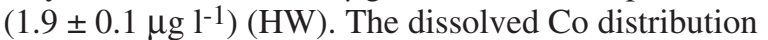
presents the same profile as that of total Co. In July 1999, the concentration of dissolved Co was $0.46 \pm$ $0.3 \mu \mathrm{g} \mathrm{l}^{-1}$ and, in $\mathrm{HW}$, the peak started in March $(0.42$ $\left.\pm 0.02 \mu \mathrm{g} \mathrm{l}^{-1}\right)$ and reached its maximum concentration in April $2000\left(0.51 \pm 0.07 \mu \mathrm{g} \mathrm{l}^{-1}\right)$. In LW, except for July 1999, the concentration of dissolved Co remained constant $\left(0.14 \pm 0.08 \mu \mathrm{g}^{-1}\right)$.
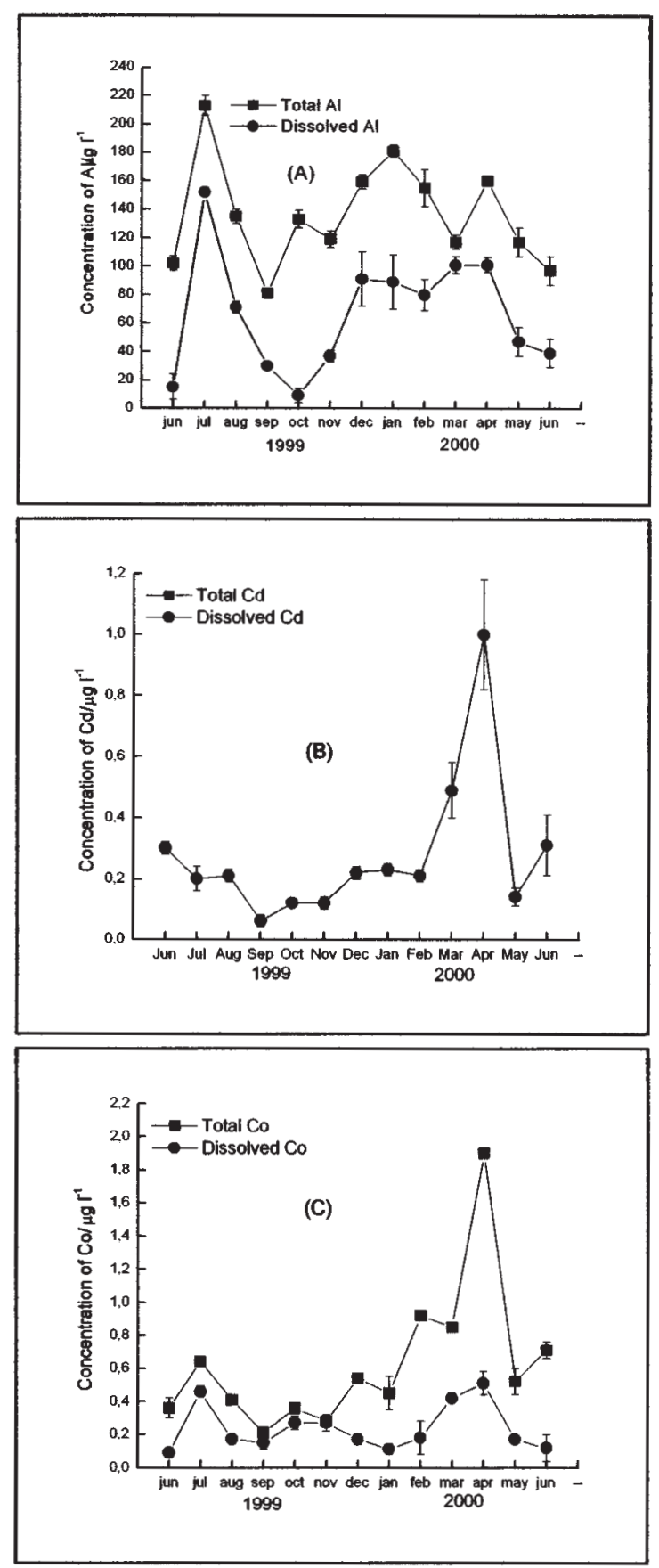

Fig. 3. Distributions of $\mathrm{Al}(\mathrm{A}), \mathrm{Cd}(\mathrm{B})$, and $\mathrm{Co}(\mathrm{C})$ concentrations $\left(\mu \mathrm{g}^{-1}\right)$ in Lake Ipê between June 1999 and June 2000. Total metal : non filtered water. Dissolved metal : filtered water. 
Chromium - Chromium appeared preferentially as dissolved $\mathrm{Cr}$ in all months with two concentration peaks, in July $1999\left(4.8 \pm 1.2 \mu \mathrm{g}^{-1}\right)$ and in March and April $2000\left(9.0 \pm 0.1 \mu \mathrm{g} \mathrm{l^{-1 }}\right)$ (Fig. 4A).

Copper - Maximum concentrations of total $\mathrm{Cu}$ in LW occurred in July $1999\left(3.2 \pm 1.3 \mu \mathrm{g} \mathrm{l}^{-1}\right)$ and two peaks were observed in HW, in January $(3,3 \pm 1.2 \mu \mathrm{g}$ $\left.\mathrm{1}^{-1}\right)$ and April $2000\left(2.8 \pm 0.6 \mu \mathrm{g} \mathrm{l}^{-1}\right)$ (Fig. 4B). Maximum concentrations of dissolved $\mathrm{Cu}$ were determined in July $1999\left(2.9 \pm 0.8 \mu \mathrm{g} \mathrm{l}^{-1}\right)$ and April $2000(2.8 \pm 0.1$ $\left.\mu \mathrm{g} \mathrm{l}^{-1}\right)$. During the entire period, concentrations of dissolved $\mathrm{Cu}(>60 \%)$ were predominant agreeing the observation that copper present in natural waters of lakes is found mainly as dissolved free ions or soluble colloidal organic complexes Borg (1995).

Nickel - Between June 1999 and June 2000, the lake remained with $100 \%$ of $\mathrm{Ni}$ in the dissolved form (Fig. 4C). Such behavior of the lake regarding $\mathrm{Ni}$ is in agreement with Borg's finding (1995). In the LW period, the concentration of dissolved $\mathrm{Ni}$ was $18.2 \pm 3.9$ $\mu \mathrm{g} \mathrm{l}^{-1}$. In $\mathrm{HW}$, the concentration of dissolved $\mathrm{Ni}$ increased gradually, reaching its maximum in April 2000 $\left(127.3 \pm 3.7 \mu \mathrm{g} \mathrm{l}^{-1}\right)$.

Zinc - Zinc appeared predominantly in the dissolved form, both in the LW and HW periods (Fig. 5A). In July 1999 , the dissolved $\mathrm{Zn}$ concentration $\left(30 \pm 4 \mu \mathrm{g}^{-1}\right)$ was higher than the average of the other months in LW $\left(19 \pm 8 \mu \mathrm{g}^{-1}\right)$. The dissolved $\mathrm{Zn}$ concentration gradually increased in $\mathrm{HW}$, reaching its maximum value $\left(70 \pm 10 \mu \mathrm{g} \mathrm{l}^{-1}\right)$ in April 2000.

Lead and Tin - It could be observed that in most months $\mathrm{Pb}$ and $\mathrm{Sn}$ appeared preferentially in the dissolved form (Figs 5B, 5C), while the concentrations of dissolved $\mathrm{Pb}\left(4.5 \pm 1.5 \mu \mathrm{g} \mathrm{l}^{-1}\right)$ and $\mathrm{Sn}\left(1.8 \pm 0.6 \mu \mathrm{g} \mathrm{l}^{-1}\right)$ did not suffer any variations. As for other metals the concentration peaks also occurred in April 2000, $9.0 \pm$ $1.0 \mu \mathrm{g} \mathrm{l}^{-1}$ and $4.9 \pm 0.3 \mu \mathrm{g} \mathrm{l}^{-1}$, respectively for dissolved $\mathrm{Pb}$ and $\mathrm{Sn}$, and according to the specification given by Borg (1995), $\mathrm{Pb}$ in lake waters occurs mostly as a colloidal organic complex.

\section{Physical and chemical parameters}

The basic water physical and chemical parameters (temperature, conductivity, alkalinity, Eh) were determined to elucidate in which chemical form the trace metals were available. Water temperature remained above $18^{\circ} \mathrm{C}$ from June 1999 to June 2000, with an average of $24 \pm 6^{\circ} \mathrm{C}$. In July 1999 (LW), the conductivity of the water column was $36.67 \pm 5.57 \mu \mathrm{S} \mathrm{cm}^{-1}$, and it was $54.20 \pm 1.48 \mu \mathrm{S} \mathrm{cm}^{-1}$ in April $2000(\mathrm{HW})$. The contribution of the transition metals in conductivity was mostly due to the high $\mathrm{Fe}^{2+}$ concentration of 0.69

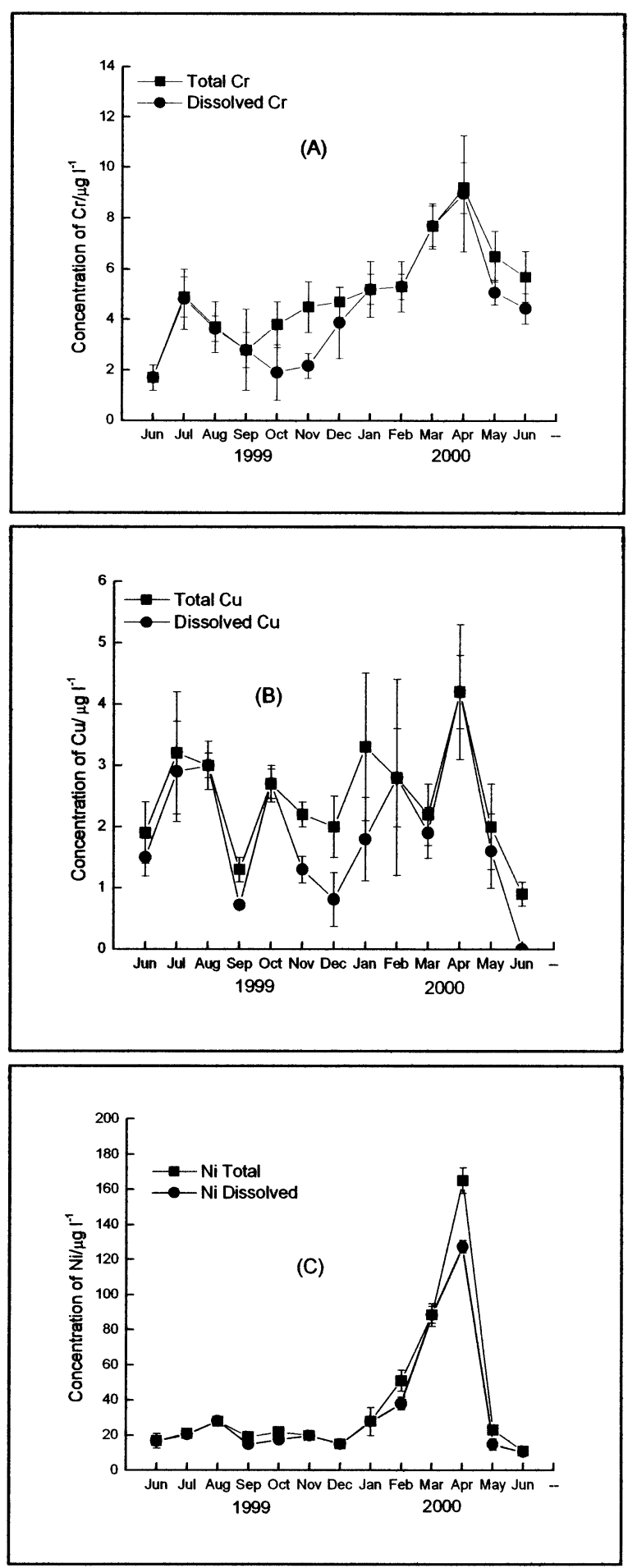

Fig. 4. Distributions of $\mathrm{Cr}(\mathrm{D}), \mathrm{Cu}(\mathrm{E})$, and $\mathrm{Ni}(\mathrm{F})$, concentrations $\left(\mu \mathrm{g} \mathrm{l}^{-1}\right)$ in Lake Ipê between June 1999 and June 2000. Total metal : non filtered water. Dissolved metal : filtered water. 

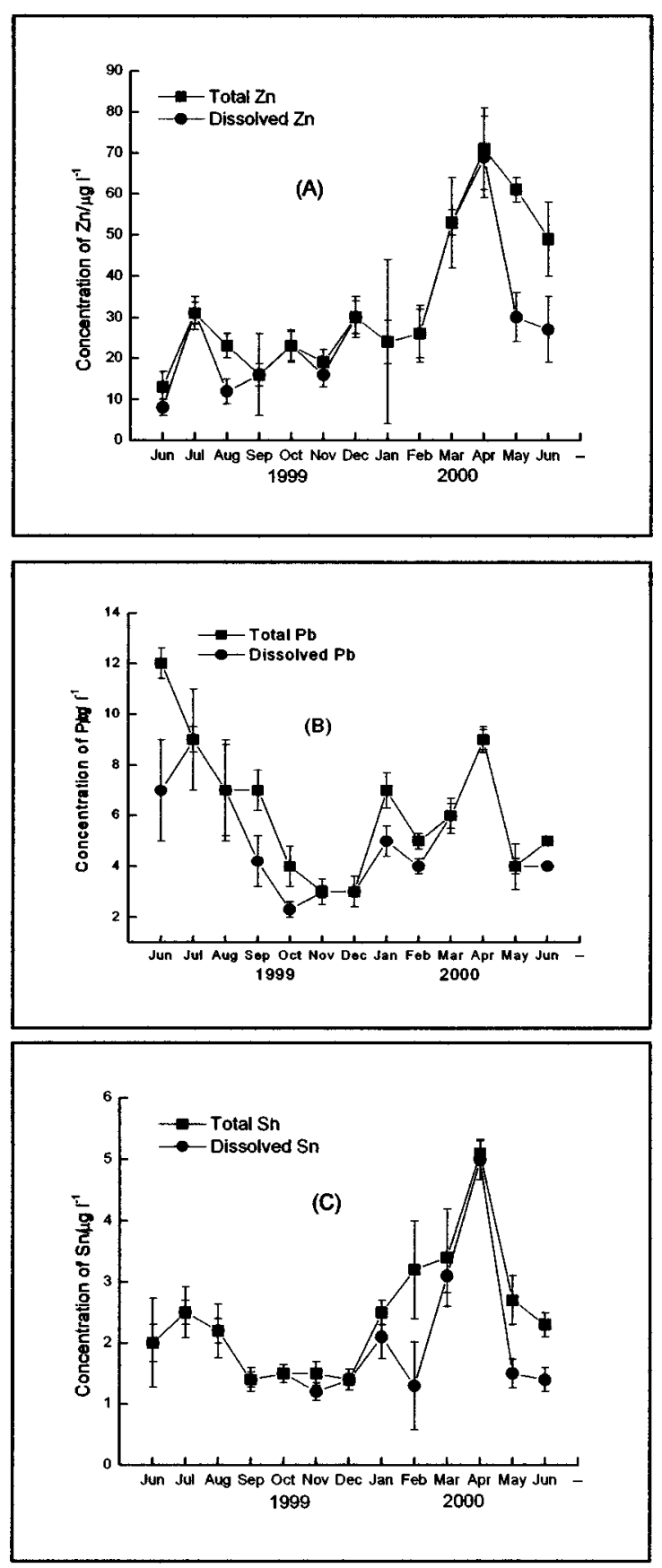

Fig. 5. Distributions of $\mathrm{Zn}(\mathrm{G}), \mathrm{Pb}(\mathrm{H})$, and $\mathrm{Sn}(\mathrm{I})$ concentrations ( $\mu \mathrm{g}$ $\left.\mathrm{l}^{-1}\right)$ in Lake Ipê between June 1999 and June 2000. Total metal : non filtered water. Dissolved metal : filtered water. $\pm 0.03 \mathrm{mg} \mathrm{l}^{-1}$ in July 1999 and $9.26 \pm 0.32 \mathrm{mg} \mathrm{l}^{-1}$ in April 2000, predominantly in relation to the sum of the other metals.

Alkalinity presented values that oscillated between 7.3 and $14.3 \mathrm{mg} \mathrm{CaCO}_{3} \mathrm{l}^{-1}$. The average observed value was $12 \pm 3 \mathrm{mg} \mathrm{CaCO}_{3} \mathrm{l}^{-1}$ and the highest values of alkalinity occurred in $\mathrm{HW}$, with an extreme value in April 2000 (14.3mg $\left.\mathrm{CaCO}_{3} \mathrm{l}^{-1}\right)$. The seasonal variation of this parameter was similar to that observed for conductivity, also verified by Thomaz et al (1992) for the Paraná and Ivinheima Rivers. The average Eh values between June 1999 and June2000 were $230 \pm$ $32 \mathrm{mV}$, mostly indicating an aerobic environment (Rump \& Krist 1992). The temporal pH variation was from 7.70 to 6.90 , with an annual average of $6.58 \pm$ 0.36 . To complete the description of physical chemical conditions of the Lake Ipê, for the MINTEQA2 calculation, the concentrations of dissolved organic carbon (DOC), dissolved oxygen (DO), reactive silica, phosphorus, sulphate, chlorophyll-a, nitrate, $\mathrm{Fe}, \mathrm{Mn}, \mathrm{Al}$, $\mathrm{Cd}, \mathrm{Co}, \mathrm{Cr}, \mathrm{Cu}, \mathrm{Pb}, \mathrm{Sn}, \mathrm{Ni}$, and $\mathrm{Zn}$ were determined.

\section{MINTEQA2 geochemical calculations}

The results of geochemical calculations were compared to PCA correlations in order to elucidate how the metals were present in water. The speciation of metals in aqueous medium is just as important as the results concerning its quantification.

Cadmium's correlation among all the variables was high for dissolved Cd and DOC (0.91) on PC1, and the MINTEQA2 calculations confirmed this observation, showing that the species present were mainly $\mathrm{Cd}^{2+}$ (90.85-86.64\%) and Cd-DOM (8.86-13,11\%), where DOM is the dissolved organic matter. Results suggest that the localized rainfalls that occurred in July 1999, in LW, did not lixiviate $\mathrm{Cd}$ to the inner part of the lake and the concentration of dissolved $\mathrm{Cd}$ in that period was $0.11 \pm 0.05 \mu \mathrm{g} \mathrm{l}^{-1}$. The water level of the Paraná river is the most important influence to explain the $\mathrm{Cd}$ presence in Lake Ipê.

The calculations showed that, from June 1999 to June $2000,99.92 \pm 0.09 \%$ of $\mathrm{Al}$ present in the lake waters were insoluble species, such as diaspore mineral (naturally hydrated alumina, belonging to the orthorhombic system). Nevertheless, Figure 3A shows that the content of dissolved $\mathrm{Al}$ was much higher than $0.08 \%$. This difference may be attributed to the presence of $\mathrm{Al}^{3+}$ complexed with organic matter in the colloidal form, able to pass through the $0.45 \mu \mathrm{m}$ filter.

The correlation between total $\mathrm{Fe}$ and $\mathrm{Co}$ was high (0.907), whereas the correlation between dissolved $\mathrm{Fe}$ 
and dissolved Co was only 0.164. The maximum and minimum correlations may be associated with the presence of the $\mathrm{CoFe}_{2} \mathrm{O}_{4}$ mineral, as precipitated and observed by theoretical calculations. Results of the analyses by X-ray fluorescence with dispersive energy (EDXRF) carried out on the residues retained in the filters $(0.45 \mu \mathrm{m})$, on samples of waters from the lake bottom (April 2000, May and June 2000) showed that there was an association of these two elements in their particulate forms in waters (unpublished results).

MINTEQA2 calculations showed that the dissolved fraction of copper must be highly complexed as $\mathrm{Cu}-$ DOM (76.88 and 80.67\%) and free ion $\mathrm{Cu}^{2+}(22.07$ and $13.39 \%$ ), in July 1999 and April 2000, respectively, coincident with the two DOC peak and water level (Fig. 2). The average percentages in other months of LW and HW were, respectively : Cu-DOM (56.45 \pm $9.40 \%$ and $60.00 \pm 12.00 \%), \mathrm{Cu}^{2+}(29.84 \pm 2.33 \%$ and $25.79 \pm 6.02 \%$ ). Pearson's correlation between dissolved $\mathrm{Cu}$ and DOC was 0.600 , confirming these theoretical results.

Zinc species in the dissolved fraction could be distributed among the main chemical species $\mathrm{Zn}^{2+}$ $(86.97 \%)$ and Zn-DOM (12.06\%) in July 1999 and in the other LW months. In March and April 2000, respectively, $\mathrm{Zn}^{2+}(85.44$ and $79.50 \%)$, Zn-DOM (13.21 and $19.07 \%$ ) were found whereas for the other HW months, $\mathrm{Zn}^{2+}$ was $91.62 \%$ and $\mathrm{Zn}-\mathrm{DOM}$ was $6.48 \%$. Correlations between dissolved $\mathrm{Ni}$ and $\mathrm{Zn}$ with DOC were equal to 0.736 and 0.743 , respectively. The calculations also show that the percentages of Ni-DOM (March and April 2000) and Zn-DOM (July 1999, March and April 2000) were higher in relation to the other months, coinciding with the maximum concentrations of DOC found in the lake. Thus, it may be considered that the fraction of dissolved $\mathrm{Ni}$ and $\mathrm{Zn}$ transported to the inner part of the lake would be associated to DOM. Since in LW the concentration of dissolved Ni remained constant, it was possible to conclude that the rainfalls in the region, in July 1999, did not alter the concentration of that element in the lake. However, in $\mathrm{HW}$, with the interference of waters from Paraná River, influxes of that element occurred. Finally, the equilibrium calculation showed that the highest percentage of $\mathrm{Pb}$ in samples of filtered waters was associated with DOM (89\% for April 2000). Nevertheless chromium was calculated in all months as $100 \%$ $\mathrm{Cr}^{3+}$.

\section{Conclusion}

Variations of metal contents along the year are mainly due to the water level of the Paraná River. During the LW period, when the Parana River water level is low, the metal concentrations are low and maintained practically constant along the months. However when the level increased gradually during four months, during $\mathrm{HW}$, it caused a concomitant increase in the concentrations of total and dissolved metals in the lake waters. Dissolved organic carbon made available most trace metals. The geochemical calculations confirmed that in the physicochemical conditions of the Lake Ipê, the metals form high concentration of soluble complexes in the months that present maximum in DOC concentration.

The lake could be classified by ECE parameters as class V for aluminium, III for cadmium, II (in LW) and III (in HW) for chromium, II for copper and zinc and IV for lead. The water quality of Lake Ipê (under the ECE metals standard classification of freshwater quality for the maintenance of aquatic life) indicated a concerned situation for a lake located in a natural and preserved region. The relation between metal concentration and Paraná River was clearly defined but its source is not so evident. The presence of these trace metals explained as a result of waste matter transported by the Paraná River is not obvious. It is difficult to understand how waste matters introduced into the Tietê River in São Paulo city could be carried down until the Paraná River, crossing several dams along the Tietê and Paraná River. These dams serve as depositories of waste matter, including residual metals, by sedimentation along the ca. $400 \mathrm{~km}$ route from the origin. So, we need to consider the necessity of another hypothesis based on geochemical composition of the lake region.

It is possible that the high levels of trace metals connected with the rising of the Parana River level could be related with the underground water around the lake. The growing level of the underground water associated with the characteristics of the underground soil, constituted by peat, could explain the metal appearance in the lake water. The hypothesis is that metals were moistened in the peat but they could be solubilized and brought up into the lake by the underground water when the Paraná River rose. The Paraná River, or localized rains, could have a strong influence on the underground water level on the Lake Ipê region in these particular periods, and so the high trace metal contents in Lake Ipê in these periods could be the result of a natural geochemical process and not human pollution.

\footnotetext{
Acknowledgements

Sônia R. G. Barreto thanks CAPES/PICDT/UEL for a scholarship and CNPq for financial support. The authors thank Dr. Roy E.
} Bruns for the careful reading of the manuscript. 


\section{References}

Allison J.D., Brown D.S. \& Novo-Gradac K.J. 1999. - MINTEQA2 A geochemical assessment data base and test cases for environmental systems. Version 4.0. Report EPA/600/3-91/-21.

Barreto S.R.G., Nozaki J. \& Barreto W.J. 2003. - Origin of dissolved organic carbon studied by UV-vis spectroscopy. Acta Hydrochim. Hydrobiol., 31, 513-518.

Barreto S.R.G., Nozaki J., de Oliveira E., do Nascimento Filho V.F., Aragão P.H.A., Scarminio I.S. \& Barreto W.J. 2004. - Comparison of metal analysis in sediments using EDXRF and ICP-OES with the $\mathrm{HCl}$ and Tessie extraction methods. Talanta, 64, 2, 345354.

Barreto W.J., Ribeiro M.R., Solci M. C., Scarminio I.S., Nozaki J., De Oliveira E., Barreto S. R. G. 2005. - Interpretation of seasona variation of metals and abiotic properties in a tropical lake using multivariate analysis and MINTEQA2 program. Anal. Sciences, in press.

Borg H. 1995. - Trace elements in lakes. Pages 177-201 in Trace elements in natural waters. Salbu B. \& Steinnes E. (eds). CRC Press, USA.

Buffle, J. 1990. - Complexation reactions in aquatic systems. An analytical approach, Ellis Horwood, England, 692 p.
Gustafsson J.P 2001. - VisualMINTEQ, version 1.03. KTH, Div. of Land and Water Resources.

Junk W.J., Bayley P.B. \& Sparks R.E. 1989. - The flood pulse concept in river-floodplain systems. Can. Spec. Publ. Fish. Aquat. Sci., 106, 110-127.

Kortelainen, P. 1999. - Source of aquatic organic carbon. Pages 4345 in Limnology of humic waters. Keskilato, J. \& Eloranta, P. (eds), Backhuys Publishers.

Neiff J.J. 1990. - Ideas to the ecological interpretation of Parana river. Intersciencia, 15, 424-441.

Rump H.H. \& Krist H. 1992. - Laboratory manual for the examination of water, waste water and soil. VCH. Weinheim, 189 p.

Scarminio I.S. \& Bruns R.E. 1989. - An adaptation of ARTHUR for microcomputers. Trends Anal. Chem., 8, 326-327.

Thomaz S.M., Roberto M.C., Lansac Tôha F.A., Lima A.F. \& Esteves F.A.1992. - Limnological characteristics at a sampling station on the upper Paraná River and other on the lower Ivinheima River - (PR, MS- Brazil). Acta Limnol. Brasil., 4, 32-51.

Train S. \& Rodrigues L.C. 1997. - Space-temporal distribution of phytoplanktonic communities. Pages105-115 in A foodplain area of high Parana river. Physical, biological and socioeconomic aspects. Vazzoler A.E.A.M., Agostinho A.A. \& Hahn N.S. (eds), EDUEM, Maringá, Brazil. 